\title{
ANALISIS PENGARUH PEMAHAMAN SISTEM MODUL PENERIMAAN NEGARA (MPN) TERHADAP TINGKAT KEPATUHAN WAJIB PAJAK PADA KPP METRO
}

(Study Kasus pada KPP Metro)

\author{
Herry Goenawan Soedarsa, Universitas Bandar Lampung \\ Fitriya Kasmawati, Universitas Bandar Lampung \\ Rosmiaty Tarmizi, Universitas Bandar Lampung
}

\begin{abstract}
The main objective of this study was to determine the perception and understanding of the corporate taxpayers Module System Revenue (MPN) and to know how to influence State Revenue System module (MPN) on tax compliance in paying taxes. Based on the analysis results, shows that the System Module Revenues have a positive influence on tax compliance in paying taxes. The system responded positively by the taxpayer, that is with a good understanding of which is owned by the taxpayer to the MPN system and increasing taxpayer compliance in paying taxes, especially in terms of formal compliance. This may imply that the expectation that the significant tax revenue from this system is not impossible.

Based on the analysis results, the researchers suggested that the MPN system can continue to be applied by the government to increase the taxpayers and increase tax revenues. However, the implementation of such a system must be balanced with the supervision and implementation of sanctions against assertion, that the implementation of sanctions still considered fair by the taxpayer who continues to do tax obligations dutifully and correctly. It is expected that the tax authorities to be more active in conducting counseling and guidance to the Taxpayer on the importance of understanding the regulatory and taxation system, especially to increase taxpayer confidence in the regulatory and taxation systems. In addition, the tax authorities have to do counseling and guidance to the Board in terms of taxpayers comply with tax laws, especially for material compliance. It is expected to cause embarrassment in selfcorporate taxpayer itself when it does not comply with tax laws. And the government should realize good governance and clean as well as improve the quality of tax officials in order to create a professional fiscus, honest / no corruption, and responsible in carrying out its duties and mandate given.
\end{abstract}

Keywords: System Module Revenues, Taxpayer, Compliance Level

\section{LATAR BELAKANG}

Kesejahteraan masyarakat suatu wilayah merupakan salah satu indikator yang dapat digunakan untuk mengetahui keberhasilan pembangunan ekonomi yang telah dicapai di suatu wilayah pada periode tertentu. Pada dasarnya pembangunan merupakan rangkaian kegiatan dari program-program di segala bidang secara menyeluruh, terarah, terpadu dan berlangsung secara terus menerus yang bertujuan meningkatkan kesejahteraan masyarakat. Untuk 
mewujudkan tujuan pembangunan tersebut, dibutuhkan biaya pembangunan yang sangat besar. Terbatasnya kemampuan keuangan negara untuk mendorong perekonomian, membuat kebijakan ekonomi makro diarahkan untuk mendorong peranan masyarakat dalam pembangunan dengan menghilangkan berbagai kendala yang menghambat.

Di samping itu, langkah-langkah kebijakan yang lebih serius akan ditempuh untuk meningkatkan pemerataan dan sekaligus mendorong potensi pembangunan yang belum termanfaat selama ini, diantaranya sektor pertanian, industri, dan di wilayah pedesaan serta efektivitas dari kebijakan fiskal akan ditingkatkan dengan mempertajam prioritas pembangunan ke dalam kegiatan-kegiatan pembangunan yang memberi dampak besar bagi masyarakat luas. Salah satu sumber pembiayaan pembangunan adalah diperoleh dari penerimaan pajak yang merupakan penerimaan negara paling potensial. Maka pemerintah berupaya meningkatkan penerimaan negara dari sektor pajak.

Pajak adalah sumber utama penerimaan negara, kurang lebih $2 / 3$ penerimaan negara saat ini bersumber dari pajak. Sehingga wajar jika saat ini optimalisasi penerimaan pajak menjadi prioritas utama. Dengan demikian, pajak merupakan sumber penerimaan yang harus dikelola dengan baik agar keuangan negara dapat berjalan dengan lancar dan baik. Dalam struktur keuangan negara, tugas dan fungsi penerimaan pajak dijalankan oleh direktorat jenderal pajak (DJP) di bawah departemen keuangan Republik Indonesia. Jenis-jenis pajak yang dikelola oleh DJP meliputi Pajak Penghasilan (PPh), Pajak Pertambahan Nilai (PPN), Pajak Bumi dan Bangunan (PBB), dan Pajak Penjualan Barang Mewah (PPnBM).

Pajak penghasilan adalah pajak yang dikenakan atas penghasilan yang merupakan tambahan ekonomis yang diterima atau diperoleh wajib pajak, baik yang berasal dari Indonesia maupun yang berasal dari luar Indonesia yang dapat dipakai untuk konsumsi atau menambah kekayaan wajib pajak (WP) yang bersangkutan. Dalam usaha untuk meningkatkan penerimaan pajak, upaya-upaya yang dilakukan pemerintah, antara lain:

1. Ekstensifikasi wajib pajak terutama melalui program penyisiran (canvassing) wajib pajak.

2. Intensifikasi pemungutan pajak, terutama melalui pengawasan yang lebih intensif terhadap wajib pajak potensial dan peningkatan kualitas aparatur pajak.

3. Peningkatan penegakan hukum (law enforcement) serta diberlakukannya undang-undang yang baru di bidang perpajakan.

Pada umumnya wajib pajak mempunyai kecenderungan untuk menghindar dari kewajibannya dalam membayar pajak. Kecenderungan melakukan penghindaran yang dilakukan oleh wajib pajak dalam pemenuhan kewajiban perpajakan lebih banyak terjadi karena Indonesia menggunakan sistem pemungutan pajak Self Assesment. Sistem pemungutan ini memberikan peran aktif kepada wajib pajak untuk melakukan sendiri perhitungan pajak terutang, menyetorkan sendiri dan melaporkan surat pemberitahuan (SPT) sendiri. Dalam sistem ini menekankan untuk kerelaan wajib pajak dan kesadaran wajib pajak dalam mematuhi peraturan perpajakan.

Agar sistem Self Assesment berjalan secara efektif, keterbukaan, dan pelaksanaan penegakkan hukum ini dapat dilakukan dengan adanya pemeriksaan, penyelidikan pajak dan penagihan pajak. pemeriksaan merupakan instrumen yang baik untuk meningkatkan kepatuhan wajib pajak, baik formal maupun materil dari peraturan perpajakan, yang tujuan utamanya untuk menguji dan meningkatkan kepatuhan wajib pajak (Priatara 2000) kepatuhan ini sangat berdampak baik secara langsung atau tidak langsung kepada penerimaan pajak. Tingkat kepatuhan wajib pajak dicerminkan melalui SPT yang diterima oleh Kantor Pelayanan Pajak (KPP). Kepatuhan wajib pajak dalam menyetor dan melaporkan surat pemberitahuan (SPT), pemeriksaan dan penagihan pajak adalah upaya intensifikasi penerimaan pajak. kepatuhan wajib pajak merupakan bagian dari kesadaran wajib pajak itu 
sendiri. Sehingga dengan kepatuhan wajib pajak yang tinggi akan turut membantu meningkatkan penerimaan pajak. kepatuhan wajib pajak merupakan syarat agar penerimaan pajak meningkat. Salah satu alternatif peningkatan penerimaan pajak adalah peningkatan $\mathrm{PPh}$. Penerimaan $\mathrm{PPh}$ adalah $\mathrm{PPh}$ Badan dan Orang Pribadi dimana masing-masing mempunyai kontribusi yang penting dan strategi dalam menentukan penerimaan pajak secara keseluruhan. Upaya peningkatan penerimaan $\mathrm{PPh}$ diperlukan suatu perencanaan yang dapat memperkirakan tingkat penerimaan pajak yang wajar dan sesuai dengan tingkat pertumbuhan ekonomi dan pembangunan saat ini.

Untuk mempermudah wajib pajak dalam membayar kewajiban perpajakannya dan dapat membuat mereka menjadi wajib pajak yang patuh, maka pemerintah mengeluarkan suatu kebijakan dalam rangka penerimaan pajak, baik program ekstensifikasi maupun intensifikasi. Ekstensifikasi lebih berfokus pada program penigkatan jumlah wajib pajak terdaftar, sedangkan intensifikasi mengacu pada perluasan objek pajak yang dapat dikenakan pajak. Salah satu kebijakan terbaru pemerintah di bidang perpajakan adalah pelaksanaan program MPN (Modul Penerimaan Negara). Program ini menekankan pada upaya mengintegrasikan data penerimaan negara dalam sebuah sistem elektronik yang handal. Hal ini diharapkan dapat mendorong wajib pajak untuk memenuhi kewajiban perpajakannya.

Modul Penerimaan Negara (MPN) mengintegrasikan tiga sistem penerimaan yang selama ini berjalan, yaitu sistem Monitoring Pelaporan Pembayaran Pajak (MP3) oleh dirjen pajak, sistem Elektronik data intercharge (EDI) oleh dirjen bea dan cukai, dan sistem penerimaan negara (Sispen) oleh dirjen anggaran. Sistem MPN terintegrasi dengan sistem perbankan serta adanya central database di departemen keuangan untuk transaksi penerimaan yang dapat di akses oleh unit-unit terkait di lingkungan departemen keuangan. Dengan MPN, pihak bank hanya perlu melakukan satu kali input dimana hasil peng-inputan tersebut dimasukan ke suatu database yang telah tersedia dan terkoneksi dengan departemen keuangan. MPN memberikan kepastian bahwa cukup hanya dengan satu kali pemrosesan, sistem ini akan mengoneksikan 87 bank dengan lebih dari 12.000 cabangnya dan secara otomatis akan menampilkan data dengan validitas yang terjamin ke departemen keuangan. Sifat realtime MPN memungkinkan transparansi keuangan negara yang lebih optimal, karena siapapun mulai dari anggota masyarakat hingga presiden, dapat melakukan pemantauan secara reguler. Sedangkan fasilitas E-Banking yang berteknologi tinggi dan terpercaya akan memudahkan masyarakat dalam melaksanakan kewajibannya kapan saja dan dimana saja. MPN mampu menjawab tantangan untuk penerapan sistem pengelolaan keuangan di negara modern seperti sekarang ini.

Dengan pemahaman yang dimiliki oleh WP mengenai MPN tentang bagaimana cara membayar pajak dengan sistem tersebut, hal itu akan memberikan kemudahan kepada WP dalam membayar kewajiban perpajakannya karena meraka tahu dan mengerti atas kemudahan yang diberikan oleh sistem MPN dalam membayar kewajiban perpajakan. Proses membayar pajak dengan mudah dan Paradigma Penelitian. Dari penelitian di atas, maka dapat dirangkum dalam paradigma penelitian sebagai berikut: 


\begin{tabular}{|c|c|}
\hline Pemahaman Sistem Modul Penerimaan Negara (MPN) (X) & Kepatuhan Wajib Pajak \\
\hline $\begin{array}{ll}\text { - } & \text { Keakuratan } \\
\text { - } & \text { Ketepatan } \\
\text { - } & \text { Dapat dipercaya } \\
\text { - Kemudahan } \\
\text { - } & \text { Efisiensi }\end{array}$ & $\begin{array}{l}\text { Kepatuhan formal } \\
\text { Kepatuhan materil }\end{array}$ \\
\hline
\end{tabular}

Gambar 1: Paradigma Penelitian "Analisis Pengaruh Pemahaman Sistem Modul Penerimaan Negara (MPN) Terhadap Tingkat Kepatuhan Wajib Pajak (Studi kasus pada KPP Pratama Metro)"

\section{TELAAH LITERATUR DAN PENGEMBANGAN HIPOTENSI}

\subsection{Pengertian Pajak}

Adapun pengertian pajak menurut beberapa ahli adalah sebagai berikut:

Menurut P.J.A Adriani (1991:2): Pajak adalah iuran kepada negara (yang dapat dipaksakan) yang terutang oleh yang wajib membayarnya menurut peraturan-peraturan, dengan tidak mendapat prestasi kembali, yang langsung dapat ditunjuk, dan yang gunanya adalah untuk membiayai pengeluaran-pengeluaran umum berhubungan dengan tugas negara untuk menjalankan pemerintahan.

Menurut Soemitro dalam Waluyo, dan Wirawan B. Ilyas, (2000:2): Pajak adalah iuran rakyat kepada kas negara berdasarkan undang-undang (yang dapat di paksakan) dengan tidak mendapat jasa timbal (kontraprestasi) yang langsung dapat ditujukan dan yang digunakan untuk membayar pengeluran umum.

Dari pengertian-pengertian tersebut dapat disimpulkan bahwa ciri-ciri yang melekat pada pengertian pajak adalah:

1. Pajak dipungut berdasarkan undang-undang serta aturan pelaksanaannya yang sifatnya dapat dipaksakan.

2. Dalam pembayaran pajak tidak dapat ditunjukkan adanya kortaprestasi individual oleh pemerintah.

3. Pajak dipungut oleh negara baik pemerintah pusat maupun pemerintah daerah.

4. Pajak diperuntukkan bagi pengeluaran-pengeluaran pemeritah, yang bila dari pemasukannya masih dapat surplus, dipergunakan untuk membiayai Public Investment.

5. Pajak dapat pula mempunyai tujuan selain budgetair, yaitu mengatur.

\section{Fungsi Pajak}

Sebagaimana telah diketahui ciri-ciri yang melekat pada pengertian pajak dari berbagai definisi, terlihat adanya dua fungsi pajak, yaitu:

1. Fungsi Penerimaan (Budgetair)

Pajak berfungsi sebagai sumber dana yang diperuntukkan bagi pembiayaan pengeluaranpengeluaran pemerintah.

2. Fungsi Mengatur (Reguler)

Pajak berfungsi sebagai alat untuk mengatur atau melaksanakan kebijakan di bidang sosial dan ekonomi. Sebagai contoh dikenakannya pajak yang tinggi terhadap minuman keras, sehingga konsumsi minuman keras dapat ditekan. 


\section{Prinsip dan Asas Pemungutan Pajak}

Prasetyo dalam sebuah jurnal mengemukakan pendapat Fritz Neumark, seorang guru besar ilmu keuangan negara dari Jerman yang mengatakan bahwa terdapat empat prinsip yang perlu diperhatikan dalam pemungutan pajak yaitu sebagai berikut :

Revenue productivity, yaitu pajak digunakan untuk menutup pengeluaranpengeluaran pemerintah selain dari laba perusahaan pemerintah dan pencetakan uang;

Social justice, yaitu pajak berperan untuk pemerataan pendapatan;

Economic goals, yaitu pajak digunakan unuk menggalakan tujuan-tujuan umum pemerintah seperti mencegah pengangguran, kestabilan moneter dan pertumbuhan ekonomi; dan

Ease administration, yaitu bahwa biaya-biaya penghitungan, pengawasan, dan penagihan pajak harus ditekan pada tingkat serendah-rendahnya.

Namun teori dasar klasik yang paling sering dipakai sebagai asas-asas pemungutan pajak yang lazim berlaku adalah hal-hal yang dicetuskan oleh Smith dalam bukunya yang berisi :

\section{Equality (Asas Keadilan)}

"The subjects of every state ought to contribute towards the support of the government, as nearly as possible, in proportion to their respective abilities; that is, in proportion to the revenue which they respectively enjoy under the protection of the state”. Equality atau asas keadilan merupakan asas dimana dalam memungut pajak haruslah diterapkan prinsip adil dan merata. Misalnya, jika pajak akan dikenakan kepada orang-orang pribadi, maka haruslah sebanding dengan kemampuannya untuk membayar (ability to pay) dan sesuai dengan manfaat (benefit) yang diterimanya.

\section{Certainty (Asas Kepastian)}

"The tax which each individual is bound to pay ought to be certain, and not arbitrary. The time of payment, the manner of payment, the quantity to be paid, ought all to be clear and plain to the contributor, and to every other person". Certainty atau asas kepastian mempunyai arti bahwa pajak itu tidak ditentukan secara sewenangwenang, melainkan pajak itu harus dari awalnya jelas bagi semua Wajib Pajak dan seluruh masyarakat, misalnya menyangkut masalah berapa jumlah yang harus dibayar, kapan harus dibayar, dan bagaimana cara membayarnya. Apabila tidak ada kepastian dimana pada akhirnya penentuan pajak yang terutang tergantung kebijaksanaan petugas pajak, maka hal tersebut mempunyai dampak timbulnya penyalahgunaan kekuasaan untuk kepentingan pribadi.

\section{Convenience (Asas Kemudahan)}

"Every tax ought to be levied at the time, or in the manner, in which it is most likely to be convenient for the contributor to pay it". Convenience of Payment atau asas simplicity dimaksudkan bahwa pada saat wajib pajak melakukan pembayaran pajaknya, hendaknya ditentukan pada saat yang tidak akan menyulitkan. Asas ini mempertimbangkan adanya keharusan dalam pelaksanaan pembayaran dengan cara yang mudah (simple). 


\section{Efficiency (Asas Efisiensi)}

"Every tax ought to be so contrived as both to take out and to keep out of the pockets of the people as little as possible over and above what it brings into the public treasury of the state". Asas ini menekankan pentingnya efisiensi dalam pemungutan pajak, dimana mengandung pengertian biaya yang dikeluarkan dalam melaksanakan pemungutan pajak tidak boleh lebih besar dari jumlah pajak yang dipungut.

Lain halnya dengan Mardiasmo4 yang merumuskan asas-asas pemungutan pajak seperti sebagi berikut :

Asas Domisili, yaitu asas pemungutan pajak yang menyebutkan bahwa negara mempunyai hak untuk memungut pajak atas seluruh penghasilan Wajib Pajak yang bertempat tinggal di wilayahnya, baik penghasilan yang berasal dari dalam maupun dari luar negeri. Asas ini berlaku untuk Wajb Pajak Dalam Negeri (WPDN);

Asas Sumber, yaitu negara mempunyai hak untuk mengenakan pajak atas penghasilan yang bersumber atas penghasilan di wilayahnya tanpa memperhatikan dimana Wajib Pajak bertempat tinggal;

Asas Kewarganegaraan, yaitu asas pengenaan pajak yang dihubungkan dengan kearganegaraan seseorang misalnya pajak orang asing di Indonesia yang dikenakan pada setiap orang yang bukan warga negara Indonesia. Asas ini berlaku untuk Wajib Pajak Luar Negeri (WPLN).

\subsection{Pengertian Modul Penerimaan Negara (MPN)}

Modul Penerimaan Negara (MPN) adalah suatu sistem yang terstruktur untuk mengatur proses penerimaan, penyetoran, pengumpulan data, pencatatan, pengikhtisaran sampai dengan pelaporan yang berhubungan dengan penerimaan negara. MPN merupakan bagian dari Sistem Perbendaharaan dan Anggaran Negara (SPAN). Dasar hukum digunakannya modul ini adalah peraturan Menkeu Nomor 99/PMK.06/2006 tentang Modul Penerimaan Negara (MPN), peraturan Dirjen Perbendaharaan Nomor PER-78/PB/2006 tentang Penatausahaan Penerimaan Negara melalui MPN, dan peraturan Dirjen Pajak Nomor PER-148/PJ/2007 tentang Pelaksanaan MPN. Dibawah ini beberapa hal tentang MPN, diantaranya adalah sebagai berikut:

- MPN mengintegrasikan tiga sistem penerimaan yang selama ini berjalan, yaitu MP3, EDI, dan Sispen.

- Tujuan MPN adalah untuk memberikan pelayanan terbaik bagi wajib pajak dan menyediakan data pemerintah yang relevan dan reliable yang dapat digunakan oleh semua instansi terkait.

- Ruang lingkup MPN meliputi penerimaan Perpajakan, PNBN, Pengembalian Belanja, dan Penerimaan Perhitungan pihak ketiga yang disetor oleh perorangan/badan atau bendahara melalui bank persepsi/bank devisa persepsi/pos persepsi dan penerimaan yang berasal dari SPM yang dibukukan oleh KPPN.

- Sistem MPN terhubung dengan seluruh Bank/Pos Persepsi yang menerima pembayaran penerimaan negara. Bank/Pos persepsi melakukan pengesahan pembayaran penerimaan negara ke sistem MPN secara Realtime online. Kegiatan ini dilakukan setiap ada pembayaran penerimaan negara oleh Wajib Pajak/Waib Setor/Wajib bayar. Pengesahan pembayaran penerimaan negara dibuktikan dengan diterbitkannya NTPN oleh sistem MPN. 
- Setoran penerimaan dalam sistem MPN tidak hanya melalui teller/loket bank/pos, tetapi juga sudah berkembang pembayaran penerimaan negara melalui berbagai jalur yakni ebilling, ATM, dan Internet Banking.

Secara umum manfaat yang diperoleh dari penerapan Modul Penerimaan Negara sebagai suatu sistem pengelolaan penerimaan negara dapat dilihat dari dua sisi yaitu:

\section{Manfaat bagi Departemen Keuangan selaku pengelola keuangan negara}

Bagi Departemen Keuangan sangat jelas sekali terasa manfaat dari diberlakukannya Modul Penerimaan Negara ini. Berikut beberapa manfaat yang diperoleh dari MPN:

$\rightarrow$ Ruang lingkup MPN yang luas meliputi penerimaan perpajakan, Penerimaan Negara Bukan Pajak (PNBN), Penerimaan Pengembalian Belanja, dan Penerimaan Perhitungan Pihak Ketiga yang disetor oleh perorangan/badan atau yang berasal dari Surat Perintah Membayar (SPM) yang dibukukan oleh Kantor Pelayanan Perbendaharaan Negara (KPPN), menjadikan pengelolaan keuangan negara lebih mudah dilakukan.

$\rightarrow$ Secara teknis pengelolaan keuangan negara menjadi lebih efektif dan efisien, karena menggunakan sistem yang sama antara penerimaan dari Pajak, Bea Cukai serta sistem pencatatan oleh perbendaharaan.

\section{Manfaat bagi masyarakat selaku pengguna Modul Penerimaan Negara}

berikut:

Bagi masyarakat manfaat dari diberlakukannya Modul Penerimaan Negara sebagai

$\Rightarrow$ Adanya kemudahan, karena MPN adalah layanan setoran on-line selama 24 jam yang dapat dilakukan dari mana saja serta fleksibel karena dapat dilakukan melalui berbagai fasilitas pembayaran pada bank/pos.

$\Rightarrow$ Adanya kepastian yang diperoleh oleh wajib pajak/bayar dengan mendapat kode penomoran yang unik dan khusus untuk setiap transaksi, menjamin validitas dan akurasi transaksi penerimaan serta monitoring penerimaan negara dapat dilakukan secara realtime.

$\Rightarrow$ Proses pembayaran dengan MPN dapat dilakukan dengan:

> Pembayaran dapat dilakukan melalui loket, wajib pajak/wajib bayar datang ke loket bank/pos dan melakukan pembayaran sebelum pukul 15.00 WIB waktu setempat,

$>$ Pembayaran melalui elektronic banking, wajib pajak/bayar mendapatkan Nomor Registrasi Pembayaran (NRP) dengan melengkapi data pada website www.djpbn.depkeu.go.id dan menggunakan NRP tersebut untuk pembayaran melalui ATM, internet banking, mobile banking, dan fasilitas e-banking lainnya.

\subsection{Kepuasan Wajib Pajak}

Kata " kepuasan atau satisfaction " berasal dari bahasa latin "satis" (artinya cukup baik, memadai) dan "facio" (melakukan dan membuat). Berikut ini defenisi kepuasan konsumen dari beberapa pakar ekonomi, yaitu :

a. Menurut Howard \& Shets (dalam Tjiptono, 2005:349) mengungkapkan bahwa kepuasan konsumen adalah situasi kognitif pembeli berkenaan dengan kesepadanan atau ketidaksepadanan antara hasil yang didapatkan dibandingkan dengan pengorbanan yang dilakukan.

b. Menurut Wetbrook \& Reilly (dalam Tjiptono, 2005:349) berpendapat bahwa kepuasan konsumen merupakan respon emosional terhadap pengalaman-pengalaman berkaitan 
dengan produk atau jasa tertentu yang dibeli, gerai ritel, atau bahkan pola perilaku (perilaku berbelanja, dan perilaku pembeli), serta pasar secara keseluruhan.

c. Menurut Mowen (dalam Tjiptono, 2005:349) merumuskan "kepuasan konsumen adalah sikap keseluruhan terhadap suatu barang atau jasa setelah perolehan (acquition) dan pemakainnya".

\section{METODE PENELITIAN}

\subsection{Objek Penelitian}

Objek penelitian dalam skripsi ini adalah wajib pajak pada KPP Metro, dimana KPP metro itu sendiri beralamat di Jalan Unyi Kauman Bawah Nomor 66. Kantor tersebut dibangun pada tahun 1993 dan selesai tanggal 1 April 1995, kemudian diresmikan pada tanggal 26 Mei 1995.

\section{Populasi}

Populasi (Universe) adalah keseluruhan subjek penelitian (arikunto, 1998:115), atau kumpulan dari individu dengan kualitas serta ciri-ciri yang telah ditetapkan (nazir, 2003:352). Encyclopedia of Educational Evaluation dalam arikunto (1995:115) menjelaskan bahwa: "a population is a set (or collection) of all element possesing one or more attributes of intrest". Dalam penelitian ini ditentukan sebagai populasi adalah seluruh wajib pajak badan pada KPP Pratama Metro yang memanfaatkan sistem MPN di Kantor Pelayanan Pajak Pratama Metro yang berjumlah 879 wajib pajak badan. Tidak seluruh populasi tersebut akan diteliti, namun penelitian hanya akan mengambil sampel yang dianggap representatif.

\section{Sampel}

Oleh karena populasi terbatas dan diketahui pengambilan sampel dapat dilakukan dengan purposive sampling (Singgih Santoso dan Fandly Tjiptano, 2001:89-90). Sampling Purposive adalah teknik penentuan sampel dengan pertimbangan tertentu (Sugiyono, 2004:78). Berdasarkan pendapat tersebut maka sampel dalam penelitian ini adalah bersifat purposive sampling atau berdasarkan penunjukan, dikarenakan populasi yang ada terbatas pada Kantor Pelayanan Pajak Pratama Metro.

Prosedur pengambilan sampel yang digunakan penulis sesuai dengan pendapat Arikunto (2002:112) bahwa "untuk sekedar ancer-ancer maka apabila subyeknya kurang dari 100, lebih baik diambil semua. Selanjutnya jika jumlah subyeknya besar dapat diambil antara $10 \%-15 \%$ atau $20 \%-25 \%$ atau lebih".

Jumlah sampel dalam penelitian ini berdasarkan prosedur pengambilan sampel dari jumlah populasi 879 wajib pajak badan, akan diambil $10 \%$ dari jumlah populasi yaitu sebanyak 88 wajib pajak badan.

\subsection{Metode Pengumpulan Data}

1. Studi Pustaka (Library Research)

Studi pustaka adalah studi yang dilakukan untuk mendapatkan data sekunder dengan membaca buku/literatur atau karya ilmiah lainnya dan sumber data yang mempunyai hubungan dengan penulisan penelitian ini. 
2. Penelitian Lapangan (Field Research)

Penelitian lapangan dipergunakan untuk mendapatkan data langsung dari objek penelitian (WP pada KPP Pratama Metro). Dalam penelitian lapangan digunakan teknik pengumpulan data sebagai berikut:

a. Observasi

Suatu teknik pengumpulan data yang dilakukan dengan pengamatan secara langsung terhadap objek yang diteliti (WP pada KPP Pratama Metro) yang berhubungan dengan topik pembahasan peneliti.

b. Dokumentasi

Metode ini digunakan untuk mengumpulkan data yang didapat dari dokumen yang telah diterbitkan dengan buku, majalah, internet, dan hasil penelitian terdahulu yang berhubungan dengan penelitian.

c. Wawancara

Teknik pengumpulan data dengan mengadakan tanya jawab langsung dengan pimpinan, karyawan dan wajib pajak (responden) yang bersangkutan tentang hal-hal yang berhubungan dengan bidang yang diteliti dalam penelitian ini.

d. Kuesionner

Suatu teknik pengumpulan data yang dilakukan dengan memberikan formulir pertanyaan yang sudah dengan pilihan jawaban tersedia kepada wajib pajak, untuk mendapatkan data mengenai masalah yang diteliti, yaitu apakah pemahaman terhadap sistem modul Penerimaan Negara (MPN) berpengaruh terhadap tingkat kepatuhan wajib pajak pada KPP Metro? Penulis membuat pertanyaan yang mengacu pada indikator masing-masing variabel.

\section{Operasional Variabel dan Pengukuran Variabel}

Operasional variabel menjelaskan variabel-variabel sesuai dengan fungsi atau kedudukan sebagai sebagai variabel independent $(\mathrm{X})$ dan variabel dependent $(\mathrm{Y})$. Dalam penelitian ini yang merupakan variabel independent $(\mathrm{X})$ adalah pemahaman sistem Modul Penerimaan Negara (MPN), sedangkan variabel dependent (Y) adalah kepatuhan wajib pajak, dengan indikator-indikator sebagai berikut:

a. Pemahaman Sistem Modul Penerimaan Negara ditekankan pada pemahaman responden/ wajib pajak mengenai keakuratan, ketepatan, relevansi, dapat dipercaya, kemudahan, dan efisiensi Sistem Modul Penerimaan Negara (MPN).

b. Kepatuhan wajib pajak yang tercermin pada kepatuhan formal dan kepatuhan materil dalam sistem perpajakan.

c. Indikator dari setiap variabel di atas dijadikan dasar untuk menyusun daftar pertanyaan yang diberikan kepada responden. Data yang terkumpul melalui daftar pertanyaan merupakan data kualitataif kemudian selanjutnya diubah menjadi data kuantitatif dengan cara pemberian nilai pada masing-masing jawaban, terdapat 5 skala tingkatan nilai yaitu:

Tabel 1: Skala tingkatan nilai

\begin{tabular}{|l|l|l|}
\hline NO & Skala Tingkatan & Score \\
\hline a. & Tidak Setuju & 1 \\
\hline b. & Kurang Setuju & 2 \\
\hline c. & Cukup Setuju & 3 \\
\hline d. & Setuju & 4 \\
\hline e. & Sangat Setuju & 5 \\
\hline
\end{tabular}

Sumber: J. Supranto (2010:245) 


\subsection{Metode Analisa Data}

Setelah melakukan pengumpulan data, maka dilakukan suatu analisis untuk mengolah data lebih lanjut dan melakukan pengujian terhadap hipotesa.

\section{Analisis Kualitatif}

Dalam analisis kualitataif akan membahas mengenai hasil penelitian dengan memberikan penilaian terhadap jawaban responden melalui penyebaran kuesioner yang telah diisi responden. Skala yang digunakan adalah skala likert dan skala interval.

1. Skala interval, mengetahui tanggapan responden terhadap variabel penelitian. Skala interval mempunyai kriteria penilaian 1-5, dengan rumus sebagai berikut:

$$
\mathrm{I}=\frac{\text { Nilai tertinggi }- \text { Nilai terendah }}{\text { Kategori }}
$$

2. Skala likert, untuk mengetahui tanggapan responden terhadap masing-masing butir instrument indikator. Skala likert mempunyai kriteria penilaian 1-5 dengan demikian dapat dibuat kriteria penilaian dengan rumus sebagai berikut:

$$
\mathbf{I}=\frac{\text { Skor Tertinggi-Skor terendah }}{\text { Kategori }}
$$

\section{Analisis Kuantitatif}

Pada analisis kuantitatif akan menganalisis Pengaruh Pemahaman Sistem Modul Penerimaan Negara (MPN) (X) terhadap Tingkat Kepatuhan Wajib Pajak (Y) dengan menggunakan persamaan regresi linier sederhana, karena variabel bebas hanya satu dan penulis ingin melihat bagaimana pengaruh variabel bebas terhadap variabel terikat.

Dalam analisis regresi sederhana ini, hubungan fungsional antara variabel bebas (X) dengan variabel terikat (Y) dinyatakan dengan model:

$$
\mathbf{Y}=\mathbf{a}+\mathbf{b X}+\mathbf{e t}
$$

\section{Keterangan:}

$\mathrm{a}=$ Konstanta

$\mathrm{b}=$ koefisien parameter $\mathrm{X}$ atau koefisien regresi

et $=$ error of term

Langkah-langkah analisis:

1. Menentukan nilai a dan $b$ dari model persamaan $\mathbf{Y}=\mathbf{a}+\mathbf{b X}+\mathbf{e t}$, dimana "a" adalah konstanta dan "b" adalah koefisien parameter $\mathrm{X}$ atau koefisien regresi.

2. Melakukan uji statistik, uji statistik dilakukan untuk menguji signifikasi koefisien regresi yang diperoleh. Langkah-langkah untuk melakukan uji t adalah:

\section{a. Penentuan Hipotesis}

Ho : Tidak terdapat pengaruh yang signifikan antara Pemahaman Sistem Modul Penerimaan Negara (MPN) (X) terhadap kepatuhan wajib pajak (Y).

Ha : Terdapat pengaruh yang signifikan antara Pemahaman Sistem Modul Penerimaan Negara (MPN) (X) terhadap kepatuhan wajib pajak (Y). 


\section{b. Uji hipotesis}

Dasar pengambilan keputusan adalah dengan membandingkan nilai thitung dengan ttabel.

- Jika statistik thitung >ttabel, maka Ho ditolak dan terima Ha.

c. Uji statistik

○ Jika statistik thitung $<$ ttabel, maka Ho diterima dan tolak Ha.

Membandingkan antara statistik thitung dengan ttabel, maka kesimpulan dapat diambil, apakah menerima Ha atau menolak Ho.

\section{HASIL DAN PEMBAHASAN}

\subsection{Deskripsi Masing-masing Karakteristik Responden}

Data yang digunakan dalam penelitian ini merupakan hasil dari kuesioner yang disebar kepada WP Badan khususnya WP yang memanfaatkan Sistem MPN di KPP Metro selaku responden. Jumlah kuesioner yang dapat disebar adalah 88 kuesioner. Berikut perincian penyebaran dan penerimaan kuesioner.

Gambar 2

\section{Penyebaran dan Pengumpulan Data}

\begin{tabular}{|lc|}
\hline Jumlah kuesioner yang disebar & 88 \\
Jumlah kuesioner yang tidak kembali & 0 \\
Jumlah kuesioner kembali & 88 \\
Jumlah kuesioner yang diolah & 88 \\
Tingkat pengembalian (response rate) & $100 \%$ \\
$(88 / 88 \times 100 \%)$ & \\
Tingkat pengembalian yang diolah (usable response rate) & $100 \%$ \\
$(88 / 88 \times 100 \%)$ & \\
\end{tabular}

Sumber: data diolah dari hasil kuesioner, 2012

Berdasarkan data yang diperoleh dari hasil penelitian, dapat dijelaskan pula mengenai karakteristik responden. Karakteristik responden digunakan untuk mengetahui gambaran umum tentang WP Badan khususnya WP yang memanfaatkan Sistem MPN di KPP Metro yang terpilih sebagai responden dapat dilihat pada tabel berikut:

\section{Jenis Usaha}

Tabel 2

Diskripsi Karakteristik Responden Berdasarkan Jenis Usaha

\begin{tabular}{|l|l|l|l|}
\hline No. & Jenis Usaha & Frekuensi & Presentase \\
\hline 1. & Perdagangan & $\mathbf{2 9}$ & $\mathbf{3 2 , 9 5 \%}$ \\
\hline 2. & Jasa & 37 & $\mathbf{4 2 , 0 5 \%}$ \\
\hline 3. & Manufaktur & $\mathbf{2 0}$ & $\mathbf{2 2 , 7 3 \%}$ \\
\hline 4. & Lainnya & $\mathbf{2}$ & $\mathbf{2 , 2 7 \%}$ \\
\hline Jumlah & $\mathbf{8 8}$ & $\mathbf{1 0 0 \%}$ & \multicolumn{1}{|l}{} \\
\cline { 1 - 2 } & & &
\end{tabular}

Sumber: data diolah dari hasil kuesioner, 2012 
Dari hasil penyebaran kuesioner, diketahui bahwa 29 responden $(32,95 \%)$ bekerja di perusahaan Dagang, 37 responden $(42,05 \%)$ bekerja diperusahaan Jasa, 20 responden $(22,73 \%)$ bekerja di perusahaan Manufaktur dan 2 responden $(2,27 \%)$ bekerja di perusahaan selain yang tercantum pada kuesioner. Dimana dari hasil kuesioner yang disebarkan, responden yang mendominasi adalah yang bekerja di perusahaan dengan jenis usaha Jasa.

\section{Jenis kelamin}

Tabel 3

Deskripsi Karakteristik Responden Berdasarkan Jenis Kelamin

\begin{tabular}{|c|c|c|c|}
\hline No. & Jenis Kelamin & Frekuensi & Presentase \\
\hline 1 & Laki-Laki & $\mathbf{4 1}$ & $\mathbf{4 6 , 5 9 \%}$ \\
\hline 2 & Perempuan & 47 & $\mathbf{5 3 , 4 1 \%}$ \\
\hline Jumlah & $\mathbf{8 8}$ & $\mathbf{1 0 0 \%}$ \\
\hline
\end{tabular}

Sumber: data diolah dari hasil kuesioner, 2012

Dari hasil penyebaran kuesioner, diketahui bahwa 41 responden $(46,59 \%)$ adalah Laki-laki dan 47 responden $(53,41 \%)$ adalah Perempuan. Dimana yang mendominasi adalah perempuan

\section{Umur}

\section{Tabel 4}

Deskripsi Karakteristik Responden Berdasarkan Umur

\begin{tabular}{|c|c|c|c|}
\hline No. & Umur & Frekuensi & Presentase \\
\hline 1. & $\mathbf{2 0 - 2 5}$ & $\mathbf{3 9}$ & $\mathbf{4 4 , 3 2 \%}$ \\
\hline 2. & $\mathbf{2 6 - 3 0}$ & $\mathbf{3 3}$ & $\mathbf{3 7 , 5 \%}$ \\
\hline 3. & $\mathbf{3 1 - 3 5}$ & $\mathbf{1 3}$ & $\mathbf{1 4 , 7 7 \%}$ \\
\hline 4. & $>\mathbf{3 5}$ & $\mathbf{3}$ & $\mathbf{3 , 4 1 \%}$ \\
\hline Jumlah & $\mathbf{8 8}$ & $\mathbf{1 0 0 \%}$ \\
\hline
\end{tabular}

Sumber: data diolah dari hasil kuesioner, 2012

Dari hasil penelitian, diketahui bahwa 39 responden $(44,32 \%)$ berusia $20-25$ tahun, 33 responden $(37,5 \%)$ berusia 26-30 tahun, 13 responden $(14,77 \%)$ berusia 31-35 tahun dan sisanya 3 responden $(3,41 \%)$ berusia diatas 35 tahun. Dilihat dari segi usia, responden yang mendominasi adalah usia 20-25 tahun. 
Agama

Tabel 5

Deskripsi Karakteristik Responden Berdasarkan Agama

\begin{tabular}{|c|c|c|c|}
\hline No. & Agama & Frekuensi & Presentase \\
\hline 1. & Islam & $\mathbf{5 2}$ & $\mathbf{5 9 , 0 9 \%}$ \\
\hline 2. & Kristen & $\mathbf{1 6}$ & $\mathbf{1 8 , 1 8 \%}$ \\
\hline 3. & Katolik & $\mathbf{9}$ & $\mathbf{1 0 , 2 3 \%}$ \\
\hline 4. & Budha & $\mathbf{5}$ & $\mathbf{5 , 6 8 \%}$ \\
\hline 5. & Hindu & $\mathbf{6}$ & $\mathbf{6 , 8 2}$ \\
\hline 6. & Lainnya & $\mathbf{0}$ & $\mathbf{0 \%}$ \\
\hline \multicolumn{2}{|c|}{ Jumlah } & $\mathbf{8 8}$ & $\mathbf{1 0 0 \%}$ \\
\hline
\end{tabular}

Sumber: data diolah dari hasil kuesioner, 2012

Dari hasil perhitungan kuesioner, diperoleh hasil bahwa 52 responden $(59,09 \%)$ beragama Islam, 16 responden $(18,18 \%)$ beragama Kristen, 9 responden $(10,23 \%)$ beragama Katolik, 5 responden $(5,68 \%)$ beragama Budha, dan sisanya 6 responden $(6,82 \%)$ beragama Hindu.

\section{Pendidikan}

Tabel 6

Deskripsi Karakteristik Responden Berdasarkan Pendidikan

\begin{tabular}{|c|c|c|c|}
\hline No. & Pendidikan & Frekuensi & Presentase \\
\hline 1. & SMP & $\mathbf{0}$ & $\mathbf{0 \%}$ \\
\hline 2. & SMU/SMK & $\mathbf{1 3}$ & $\mathbf{1 4 , 7 7 \%}$ \\
\hline 3. & Diploma & 15 & $\mathbf{1 7 , 0 5 \%}$ \\
\hline 4. & S1 & $\mathbf{5 2}$ & $\mathbf{5 9 , 0 9 \%}$ \\
\hline 5. & S1 & $\mathbf{8}$ & $\mathbf{9 , 0 9 \%}$ \\
\hline 6. & Lainnya & $\mathbf{0}$ & $\mathbf{0 \%}$ \\
\hline \multicolumn{2}{|c|}{ Jumlah } & $\mathbf{8 8}$ & $\mathbf{1 0 0 \%}$ \\
\hline
\end{tabular}

Sumber: data diolah dari hasil kuesioner, 2012

Berdasarkan hasil kuesioner, diketahui bahwa 13 responden $(14,77 \%)$ berpendidikan SMU/SMK, 15 responden $(17,05 \%)$ berpendidikan Diploma, 52 responden $(59,09 \%)$ berpendidikan S1 (strata 1), dan sisanya 8 responden $((9,09 \%)$ berpendidikan S2 (Strata 2).

\subsection{Pembahasan}

\section{Analisis Kualitatif}

Analisis kualitatif yaitu menganalisis data dengan cara menguraikan jawaban pertanyaan atas dasar indikator masing-masing variabel. Untuk mengetahui presentase pencapaian score riil terhadap Pemahaman Sistem Modul Penerimaan Negara (MPN) Terhadap Tingkat Kepatuhan Wajib Pajak Perusahaan Pada KPP Metro dapat diuraikan sebagai berikut: 


\section{Menentukan Skala Interval}

Skala Interval ditetapkan dengan mengetahui:

$\mathrm{I}=\frac{\text { Nilai Tertinggi-Nilai Terendah }}{\text { Kategori }}$

$\mathbf{I}=\frac{\mathbf{5 0}-\mathbf{1 0}}{\mathbf{5}}=\mathbf{8}$

Selanjutnya berdasarkan skala interval yang telah dikategorikan sesuai jawaban dari masing-masing responden, diuraikan sebagai berikut:

\section{A. Variabel X ( Pemahaman Sistem Modul Penerimaan Negara (MPN))}

Untuk mengetahui deskripsi responden terhadap Sistem Modul Penerimaan Negara (MPN), maka dapat di lihat pada tabel 7 di bawah ini:

Tabel 7: Tabel Frekuensi Tentang Pemahaman Sistem Modul Penerimaan Negara (MPN) Berdasarkan hasil Penyebaran Kuesioner Terhadap 88 responden

\begin{tabular}{|c|c|c|c|c|}
\hline No. & Kategori & Interval & Frekuensi & Presentase \\
\hline 1 & Tidak & $10-17$ & $\mathbf{0}$ & $0 \%$ \\
\hline 2 & Kurang & $18-25$ & 2 & $2,27 \%$ \\
\hline 3 & Cukup & $26-33$ & 15 & $17,05 \%$ \\
\hline 4 & Memahami & $34-41$ & 63 & $71,59 \%$ \\
\hline 5 & Sangat & $42-50$ & 8 & $9,09 \%$ \\
\hline \multicolumn{3}{|c|}{ Jumlah } & 88 & $100 \%$ \\
\hline
\end{tabular}

Sumber:Data diolah dari hasil kuesioner, 2012

Dari tabel 7 di atas, dapat diketahui bahwa tanggapan responden terhadap Pemahaman Sistem Modul Penerimaan Negara (MPN) sebanyak 2 responden (2,27\%) menyatakan kurang memahami Sistem MPN, 15 responden (17,05\%) menyatakan cukup memahami Sistem MPN, 63 responden (71,59\%) menyatakan memahami Sistem MPN dan sebanyak 8 responden $(9,09 \%)$ menyatakan sangat memahami Sistem MPN. Dengan demikian maka dapat diketahui bahwa secara keseluruhan wajib pajak memahami sistem MPN. Artinya Sistem MPN yang diterapkan di bidang perpajakan dapat dipahami oleh para responden, dan pada umumnya para responden paham mengenai mekanisme pembayaran pajak dengan menggunakan Sistem MPN tersebut.

\section{B. Variabel Y ( Kepatuhan Wajib Pajak)}

Untuk mengetahui tingkat kepatuhan Wajib Pajak, maka dapat dilihat pada tabel 8 di bawah ini:

Tabel 8: Tabel frekuensi tentang Kepatuhan Wajib Pajak berdasarkan hasil penyebaran kuesioner terhadap 88 responden

\begin{tabular}{|c|c|c|c|c|}
\hline No. & Kategori & Interval & Responden & Presentase \\
\hline 1 & Tidak & $10-17$ & $\mathbf{0}$ & $0 \%$ \\
\hline 2 & Kurang & $18-25$ & 1 & $1,13 \%$ \\
\hline 3 & Cukup & $26-33$ & 4 & $4,55 \%$ \\
\hline 4 & Mematuhi & $34-41$ & 70 & $\mathbf{7 9 , 5 5 \%}$ \\
\hline 5 & Sangat & $42-50$ & 13 & $14,77 \%$ \\
\hline \multicolumn{3}{|c|}{ Jumlah } & 88 & $100 \%$ \\
\hline
\end{tabular}

sumber: data diolah dari hasil kuesioner, 2012 
Berdasarkan tabel 8 tersebut di atas, sebanyak 1 responden $(1,13 \%)$ menyatakan kurang mematuhi dalam membayar pajak, 4 responden (4,55\%) menyatakan cukup mematuhi dalam membayar pajak, 70 responden $(79,55 \%)$ menyatakan mematuhi dalam membayar pajak, dan yang menyatakan sangat mematuhi sebanyak 13 responden (14,77\%). Dengan demikian maka dapat diketahui bahwa tingkat kepatuhan wajib pajak dalam membayar kewajiban perpajakannya tergolong baik atau memiliki kepatuhan yang baik dalam membayar pajak, hal ini disebabkan karena wajib pajak memiliki kesadaran membayar dan pemahaman yang baik akan aturan dan sistem perpajakan, serta memiliki persepsi yang baik atas perpajakan yang ada.

\section{Hasil Tanggapan Responden Dengan Pendekatan Skala Likert}

Berdasarkan hasil pengolahan data tentang tanggapan responden terhadap instrumen indikator sebagaimana dalam lampiran, dijelaskan berdasarkan skala likert tersebut maka dapat diterjemahkan atas dasar pengelompokan skala likert dalam 5 skala tingkatan skor dengan menggunakan rumus:

$$
\begin{aligned}
& \mathrm{I}=\frac{\text { Score Tertinggi-Score Terendah }}{\text { Kategori }} \\
& \mathrm{I}=\frac{440-88}{5}=70,4=70
\end{aligned}
$$

Tabel 9: Skala Tingkatan skor

\begin{tabular}{|l|l|l|l|}
\hline No. & Skala Tingkatan & Presentase & Kategori \\
\hline 1. & $\mathbf{8 8}-\mathbf{1 5 7}$ & $\mathbf{2 0 \% - 3 5 \%}$ & Tidak memahami \\
\hline 2. & $\mathbf{1 5 8}-\mathbf{2 2 8}$ & $\mathbf{3 6 \% - 5 1 \%}$ & Kurang memahami \\
\hline 3. & $\mathbf{2 2 9 - 2 9 9}$ & $\mathbf{5 2 \% - 6 7 \%}$ & Cukup memahami \\
\hline 4. & $\mathbf{3 0 0}-\mathbf{3 7 0}$ & $\mathbf{6 8 \% - 8 3 \%}$ & Memahami \\
\hline 5. & $\mathbf{3 7 1 - 4 4 0}$ & $\mathbf{8 4 \% - 1 0 0 \%}$ & Sangat memahami \\
\hline
\end{tabular}

Berdasarkan skala tingkatan skore pada skala likert diatas yang telah dikategorikan dalam 5 kategori, maka dapat disimpulkan sebagai berikut:

\section{a. Variabel Pemahaman Sistem MPN}

Tabel 10: Tanggapan Responden Terhadap Variabel Pemahaman Sistem MPN Berdasarkan Items Pertanyaan

\begin{tabular}{|l|l|l|l|l|}
\hline Item & Score & Score Max & Presentase & Kategori \\
\hline Keakuratan & & & & \\
\hline 1 & 315 & 440 & $71,59 \%$ & Memahami \\
\hline Jumlah I & $\mathbf{3 1 5}$ & $\mathbf{4 4 0}$ & $\mathbf{7 1 , 5 9 \%}$ & Memahami \\
\hline Ketepatan & & & & \\
\hline 2 & 313 & 440 & $71,14 \%$ & Memahami \\
\hline Jumlah II & $\mathbf{3 1 3}$ & $\mathbf{4 4 0}$ & $\mathbf{7 1 , 1 4 \%}$ & Memahami \\
\hline Relevansi & & & & \\
\hline 7 & 312 & 440 & $70,91 \%$ & Memahami \\
\hline 9 & 334 & 440 & $75,91 \%$ & Memahami \\
\hline Jumlah III & $\mathbf{6 4 6}$ & $\mathbf{8 8 0}$ & $\mathbf{7 3 , 6 4 \%}$ & Memahami \\
\hline
\end{tabular}




\begin{tabular}{|l|l|l|l|l|}
\hline Dapat Dipercaya & & & & \\
\hline 5 & 306 & 440 & $69,55 \%$ & Memahami \\
\hline Jumlah IV & $\mathbf{3 0 6}$ & $\mathbf{4 4 0}$ & $\mathbf{6 9 , 5 5 \%}$ & Memahami \\
\hline Kemudahan & & & & \\
\hline 3 & 323 & 440 & $73,41 \%$ & Memahami \\
\hline 6 & 331 & 440 & $75,23 \%$ & Memahami \\
\hline 8 & 319 & 440 & $72,50 \%$ & Memahami \\
\hline Jumlah V & $\mathbf{9 7 3}$ & $\mathbf{1 . 3 2 0}$ & $\mathbf{7 3 . 7 1 \%}$ & Memahami \\
\hline Efisiensi & & & & \\
\hline 4 & 343 & 440 & $77,95 \%$ & Memahami \\
\hline 10 & 306 & 440 & $69,55 \%$ & Memahami \\
\hline Jumlah VI & $\mathbf{6 4 9}$ & $\mathbf{8 8 0}$ & $\mathbf{7 3 , 7 5 \%}$ & Memahami \\
\hline Total Jumlah & $\mathbf{3 . 2 0 2}$ & $\mathbf{4 . 4 0 0}$ & $\mathbf{7 2 , 7 7 \%}$ & Memahami \\
\hline
\end{tabular}

Sumber: data diolah dari hasil kuesioner, 2012

Berdasarkan tabel diatas, dapat disimpulkan bahwa pemahaman wajib pajak terhadap Sistem MPN dapat dikategorikan memahami, dengan jumlah skor pencapaian 3.202 dari jumlah skor maksimum 4.400. Bila dilihat dari masing-masing indikator yaitu keakuratan, ketepatan, relevansi, dapat dipercaya, kemudahan dan efisiensi, maka dari masing-masing indikator tersebut wajib pajak dikategorikan memahami Sistem MPN. Hal tersebut berarti wajib pajak memiliki pemahaman yang baik tentang Sistem MPN. Dimana wajib pajak tidak hanya tahu tentang sistem tersebut tetapi mereka juga memahami dan mengerti tentang maksud dan bagaimana pelaksanaan yang benar dalam menggunakan sistem tersebut disaat melakukan pembayaran pajak. Namun dilihat dari hasil pencapaian setiap indikator tersebut, dapat dilihat bahwa indikator dapat dipercaya memiliki presentase paling rendah yaitu 69,55\%. Maka aparat pajak sebaiknya lebih giat lagi melakukan penyuluhan mengenai Sistem MPN terutama untuk meningkatkan kepercayaan masyarakat terhadap Sistem MPN tersebut.

\section{b. Variabel Kepatuhan Wajib Pajak}

Tabel 11: Skala Tingkatan Skor

\begin{tabular}{|l|l|l|l|}
\hline No. & Skala Tingkatan Skore & Presentase & \multicolumn{1}{|c|}{ Kategori } \\
\hline 1. & $88-157$ & $20 \%-35 \%$ & Tidak mematuhi \\
\hline 2. & $158-228$ & $36 \%-51 \%$ & Kurang mematuhi \\
\hline 3. & $229-299$ & $52 \%-67 \%$ & Cukup mematuhi \\
\hline 4. & $300-370$ & $68 \%-83 \%$ & mematuhi \\
\hline 5. & $371-440$ & $84 \%-100 \%$ & Sangat mematuhi \\
\hline
\end{tabular}

Berdasarkan skala tingkatan skore pada skala likert diatas yang telah dikategorikan dalam 5 kategori, maka dapat disimpulkan sebagai berikut: 
Tabel 12: Tanggapan Responden Terhadap Variabel Kepatuhan Wajib Pajak Berdasarkan Items Pertanyaan

\begin{tabular}{|l|l|l|l|l|}
\hline Item & Score & Score & presentase & Kategori \\
\hline Kepatuhan & & & & \\
\hline 2 & 348 & 440 & $79,09 \%$ & Mematuhi \\
\hline 4 & 358 & 440 & $81,36 \%$ & Mematuhi \\
\hline 5 & 336 & 440 & $76,36 \%$ & Mematuhi \\
\hline 8 & 318 & 440 & $72,27 \%$ & Mematuhi \\
\hline 9 & 337 & 440 & $76,59 \%$ & Mematuhi \\
\hline 10 & 328 & 440 & $74,55 \%$ & Mematuhi \\
\hline Jumlah I & $\mathbf{2 . 0 2 5}$ & $\mathbf{2 . 6 4 0}$ & $\mathbf{7 6 , 7 1 \%}$ & Mematuhi \\
\hline Kepatuhan & & & & \\
\hline 1 & 358 & 440 & $81,36 \%$ & Mematuhi \\
\hline 3 & 369 & 440 & $83,86 \%$ & Mematuhi \\
\hline 6 & 303 & 440 & $68,86 \%$ & Mematuhi \\
\hline 7 & 306 & 440 & $69,55 \%$ & Mematuhi \\
\hline Jumlah II & $\mathbf{1 . 3 3 6}$ & $\mathbf{1 . 7 6 0}$ & $\mathbf{7 5 , 9 1 \%}$ & Mematuhi \\
\hline Total & $\mathbf{3 . 3 6 1}$ & $\mathbf{4 . 4 0 0}$ & $\mathbf{7 6 , 3 9 \%}$ & Mematuhi \\
\hline
\end{tabular}

Sumber: data diolah dari hasil kuesioner, 2012

Berdasarkan tabel diatas, dapat disimpulkan bahwa kepatuhan wajib pajak dalam membayar kewajiban perpajakannya dapat dikategorikan mematuhi, dengan jumlah skor pencapaian 3.361 dari jumlah skor maksimum 4.400. Bila dilihat dari masing-masing indikator yaitu kepatuhan formal dan kepatuhan materil, maka dari masingmasing indikator tersebut wajib pajak dikategorikan patuh dalam membayar kewajiban perpajakannya. Hal tersebut berarti wajib pajak memiliki kesadaran yang tinggi terhadap kewajibannya dalam hal membayar pajak kepada negara. Namun dilihat dari tingkat presentase yang dicapai oleh masing-masing indikator kepatuhan tersebut diketahui bahwa kepatuhan materil memiliki presentase lebih rendah dibandingkan dengan kepatuhan formal. Ini harus dipertimbangkan oleh KPP ataupun pemerintah, untuk lebih meningkatkan kepatuhan wajib pajak dalam membayar kewajiban perpajakannya, terutama dalam meningkatkan kepatuhan wajib pajak terhadap kepatuhan materil.

\section{Analisis Kuantitatif}

Dalam analisis kuantitatif ini digunakan Analisis Regresi Linier Sederhana, yaitu untuk mengetahui pengaruh antara variabel bebas yaitu Pemahaman Sistem MPN terhadap variabel terikat yaitu Kepatuhan Wajib Pajak.

\section{Analisis Regresi linier Sederhana}

Berdasarkan hasil pengolahan data dengan menggunakan bantuan program SPSS for windows Version 18.0, maka diperoleh hasil untuk analisis regresi linier sederhana sebagai berikut:

$\mathbf{Y}=\mathbf{a}+\mathbf{b X}$

$Y=23,681+0,399 X$ 
Berikut adalah penjelasan berdasarkan persamaan regresi linier sederhana yaitu:

a. Koefisien regresi menunjukan tanda positif $(+)$. Hal ini menandakan bahwa persamaan regresi linier sederhana tersebut memiliki hubungan yang searah yaitu peningkatan variabel $\mathrm{X}$ akan menyebabkan peningkatan variabel $\mathrm{Y}$.

b. X berpengaruh sebesar $(+)$ 0,399 berarti Pemahaman Sistem MPN berpengaruh terhadap Kepatuhan Wajib Pajak dan apabila Pemahaman Sistem MPN dinaikkan 1\% maka Kepatuhan Wajib Pajak meningkat sebesar 39,9\%.

\section{Uji hipotesis}

\section{Penentuan Hipotesis}

Ho: Tidak terdapat pengaruh yang signifikan antara Pemahaman Sistem Modul Penerimaan Negara (MPN) (X) terhadap kepatuhan wajib pajak (Y).

Ha: Terdapat pengaruh yang signifikan antara Pemahaman Sistem Modul Penerimaan Negara (MPN) (X) terhadap kepatuhan wajib pajak (Y).

Untuk menentukan penerimaan dan penolakan hipotesis dengan membandingkan nilai antara thitung dan ttabel sebagaimana terdapat pada tabel 14 di bawah ini:

Tabel 14: Uji Hipotesis Antara Variabel Bebas Pemahaman Sistem MPN (X) Terhadap Variabel Terikat Kepatuhan Wajib Pajak (Y)

\begin{tabular}{|l|l|l|l|}
\hline $\begin{array}{c}\text { Variabel } \\
\text { yang diuji }\end{array}$ & ttabel & thitung & Signifikan \\
\hline $\mathrm{X}-\mathrm{Y}$ & $\mathbf{1 , 9 8 8}$ & $\mathbf{4 , 7 1 7}$ & Signifikan \\
\hline
\end{tabular}

Dasar pengambilan keputusan adalah dengan membandingkan nilai thitung dengan ttabel.

- Jika statistik thitung>ttabel, maka Ho ditolak dan terima Ha.

○ Jika statistik thitung <ttabel, maka Ho diterima dan tolak Ha.

\section{Uji Statistik}

Uji t digunakan untuk mengetahui pengaruh masing-masing variabel bebas terhadap variabel terikat yaitu Analisis Pengaruh Pemahaman Sistem MPN terhadap Tingkat Kepatuhan Wajib Pajak pada KPP Metro. Dari hasil penelitian, didapatkan bahwa:

\section{Pengujian (thitung) terhadap Pemahaman Sistem MPN}

Didapat nilai thitung sebesar 4,717 dan ttabel 1,988 sehingga dapat ditarik kesimpulan bahwa thitung > ttabel maka Ho ditolak dan menerima Ha. Maka terdapat pengaruh positif dan signifikan antara Pemahaman Sistem Modul Penerimaan Negara (MPN) (X) terhadap kepatuhan wajib pajak (Y). 


\section{KESIMPULAN DAN SARAN}

\subsection{Kesimpulan}

1. Berdasarkan hasil analisis secara kualitatif, maka dapat disimpulkan sebagai berikut:

a. Tanggapan responden terhadap variabel $\mathrm{X}$ dikategorikan Paham dengan jumlah score pencapaian dari semua indikator Variabel $\mathrm{X}$ sebesar 3.202 dari jumlah score maksimum sebesar 4.400. Pemahaman responden terhadap Sistem MPN mencapai $72,77 \%$. Hal tersebut berarti wajib pajak memiliki pemahaman yang baik tentang Sistem MPN. Dimana wajib pajak tidak hanya tahu tentang sistem tersebut tetapi mereka juga memahami dan mengerti tentang maksud dan bagaimana pelaksanaan yang benar dalam menggunakan sistem tersebut disaat melakukan pembayaran pajak.

b. Tanggapan responden terhadap variabel Y dikategorikan patuh dengan jumlah score pencapaian dari semua indikator Variabel Y sebesar 3.361 dari jumlah score maksimum 4.400. Kepatuhan wajib pajak dalam membayar kewajiban pajaknya mencapai 76,39\%. Hal tersebut berarti wajib pajak memiliki kesadaran yang tinggi terhadap kewajibannya dalam hal membayar pajak kepada negara. Selain itu, wajib pajak juga tahu tentang manfaat dan pentingnya membayar pajak demi kepentingan dan kemajuan pembangunan negara. Ini membuat mereka sadar dan mau membayar pajak tepat waktu dengan cara yang tepat sehingga menjadikan mereka menjadi wajib pajak yang patuh, baik patuh terhadap kepatuhan formal maupun kepatuhan materil.

2. Berdasarkan hasil analisis secara kuantitatif dengan regresi linier sederhana, maka dapat disimpulkan sebagai berikut:

a. Koefisien regresi menunjukan tanda positif $(+)$. Hal ini menandakan bahwa persamaan regresi linier sederhana tersebut memiliki hubungan yang searah yaitu peningkatan variabel $\mathrm{X}$ akan menyebabkan peningkatan variabel $\mathrm{Y}$.

b. X berpengaruh sebesar $(+)$ 0,399 berarti Pemahaman Sistem MPN berpengaruh terhadap Kepatuhan Wajib Pajak dan apabila Pemahaman Sistem MPN dinaikkan 1\% maka Kepatuhan Wajib Pajak meningkat sebesar 39,9\%.

\subsection{Saran}

Diharapkan Sistem MPN dapat terus diterapkan dan ditingkatkan oleh pemerintah guna menambah Wajib Pajak, meningkatkan kepatuhan wajib pajak, dan meningkatkan penerimaan pajak yaitu dengan melakukan penyuluhan dan pengarahan kepada wajib pajak tentang pentingnya peraturan dan sistem perpajakan tersebut.

Selain itu, sebaiknya jam istirahat kantor diatur secara bergantian. Hal tersebut dimaksudkan supaya para wajib pajak yang ingin membayar pajak langsung di Kantor Pelayanan Pajak tidak lama antri dan menunggu terlalu lama untuk membayar kewajiban pajaknya tersebut.

\section{DAFTAR PUSTAKA}

Undang-Undang Negara Republik Indonesia Nomor 28 Tahun 2007 Tentang Ketentuan Umum Dan Tata Cara Perpajakan.

Undang-Undang Negara Republik Indonesia Nomor 36 Tahun 2008 Tentang Perubahan Keempat Atas Undang-Undang Nomor 7 Tahun 1983 Tentang Pajak Penghasilan. 
Peraturan Menteri Keuangan Nomor 99/PMK.06/2006 Tentang Modul Penerimaan Negara.

Peraturan Dirjen Perbendaharaan Nomor PER-78/PB/2006 Tentang Penatausahaan Penerimaan Negara Melalui MPN.

Peraturan Dirjen Pajak Nomor PER-148/PJ/2007 Tentang Pelaksanaan MPN.

Ismawan, Indra. 2001. Reformasi Perpajakan 2000.

Waluyo, 2003, Perpajakan Indonesia, Revisi Kedua, Jakarta: Penerbit Salemba Empat.

Suandy, Erly, 2005, Hukum Pajak, Revisi Ketiga, Jakarta: Penerbit Salemba Empat.

Mardiasmo, Ak, MBA, Dr., Prof., 2006, Perpajakan, Yogyakarta: CV Andi Offset.

Umar, Husein. 1998. Riset Akuntansi. Cetakan Kedua. Jakarta: PT Gramedia.

Soemitro, H Rahmat. 1998. Asas Dan Dasar Perpajakan 1. Bandung: PT. Eresco.

Arikunto, Suharsimi, 1998, Prosedur Penelitian, Suatu Pendekatan Praktik, Rineka Cipta, Jakarta.

Moh. Nazir, 2003, Metode Penelitian, Ghalia Indonesia, Jakarta.

Santoso, Singgih, 2000, SPSS Statistik Paramatrik, Elex Media Komputindo, Jakarta.

Robert, Analisis Tingkat Kepatuhan Wajib Pajak Badan Terhadap Peningkatan Penerimaan Pajak Pada KPP Pratama Kedaton, Universitas Bandar Lampung, 2011.

Yulianto, Pengaruh Kebijakan Sunset Policy Terhadap Kemauan Membayar Pajak, Universitas Bandar lampung, 2011.

\section{Sumber website:}

http:// id.shvoong.com/ social-sciences/education/ 2203596-pengertian-pemahaman/ \#ixzz1iSlk1fv2

www.pajak.go.id

www.djpbn.depkeu.go.id

www.sjdih.depkeu.go.id 